\title{
Changes in Protein Content, Protease Activity, and Amino Acid Content Associated with Heat Injury in Creeping Bentgrass
}

\author{
Yali He \\ College of Agricultural and Biological Science, Shanghai Jiao Tong University, Shanghai, 201101, \\ P.R. China \\ Xiaozhong Liu and Bingru Huang ${ }^{1}$ \\ Plant Biology and Pathology, Rutgers University, 59 Dudley Road, New Brunswick, NJ 08901
}

\begin{abstract}
Additional Index words. Agrostis stolonifera, high temperature, leaf senescence, lipid peroxidation
Aвstract. Various physiological processes may deteriorate in response to increasing temperatures, contributing to the decline in turf quality for cool-season turfgrasses during heat stress. This study was performed to investigate metabolic changes (membrane lipid peroxidation, total protein content, amino acid content, and protease activity) associated with turf quality decline for creeping bentgrass (Agrostis stolonifera Huds.) in response to gradually increasing temperatures for a short duration and prolonged exposure to lethally high temperature. Plants were subjected to increasing temperatures of $20,25,30,35$, and $40{ }^{\circ} \mathrm{C}$ for 7 days at each level of temperature [gradual heat stress (GHS)] or exposed to high temperature of $40^{\circ} \mathrm{C}$ for 28 days [prolonged heat stress (PHS)] in growth chambers. During the GHS treatment, significant decline in turf quality occurred when plants were exposed to $30{ }^{\circ} \mathrm{C}$ for 7 days; simultaneously, malondialdehyde (MDA) content increased and total protein content in shoots decreased significantly compared to those at $20^{\circ} \mathrm{C}$. Protease activity increased at $25^{\circ} \mathrm{C}$ and then decreased as temperature was elevated from 30 to $40{ }^{\circ} \mathrm{C}$ during the GHS treatment. Amino acid content decreased under GHS, beginning at $25^{\circ} \mathrm{C}$. Under the PHS treatment, turf quality declined and MDA content increased significantly, beginning at 14 days of PHS, while total protein content decreased at 7 days of PHS. Protease activity and amino acid content increased at 7 days of PHS, and then declined with longer stress duration. Our results indicated that protease activity, and amino acid and total protein content were more responsive to GHS or PHS than that of lipid peroxidation and turf quality. Changes in metabolic parameters of protease activity, amino acid and total protein content, and lipid peroxidation may contribute to leaf senescence and poor turf performance under severe or prolonged heat stress conditions for creeping bentgrass.
\end{abstract}

Cool-season turfgrasses grown in temperate regions often suffer from heat stress when temperature exceeds $24{ }^{\circ} \mathrm{C}$ (DiPaola and Beard, 1992). Loss in green color or leaf senescence is a typical symptom of heat injury in turfgrasses. Therefore, the maintenance of a green turf canopy of cool-season turfgrasses during summer months is among major concerns in turfgrass management. Understanding the underlying basis of leaf senescence induced by heat stress is essential for maintaining high quality turf of cool-season turfgrasses in warm climatic areas.

Oxidation of lipids (lipid peroxidation) of cell membranes is a ubiquitous feature of leaf senescence, which may occur during natural senescence and can be induced by environmental stresses (Thompson et al., 1987). The level of lipid peroxidation is positively correlated with membrane damage and leaf senescence, and, therefore, is used widely as a senescence indicator (Dhindsa et al., 1981). Previous studies reported that heat-induced leaf senescence and turf quality decline was associated with increased level of lipid peroxidation in creeping bentgrass (Huang et al., 2001; Larkindale and Huang, 2004; Liu and Huang, 2000) and other cool-season turfgrass species (Jiang and Huang, 2001).

In addition to lipid peroxidation, loss of proteins is often associated with heat stress injury and leaf senescence (Anderson

Received for publication 24 Feb. 2005. Accepted for publication 25 June 2005 Acknowledgments: The authors express thanks for the Center of Turfgrass Science, Rutgers Univ., for financial support of this study. Thanks also go to Dr. Shimon Rachmilevitch, Michelle DaCosta, Yan Xu, and Steve McCann for critical review of the manuscript.

${ }^{1}$ Corresponding author; e-mail address: huang@aesop.rutgers.edu and Padhye, 2004; Callis, 1995; Hensel et al., 1993; Smart, 1994). Many studies reported that protein degradation was accelerated during heat stress in various plant species (Hensel et al., 1993; Smart, 1994; Callis, 1995) including cool-season turfgrass species (He et al., 2005; Jiang and Huang, 2002). Proteins in plant cells are classified into different groups based on their solubility properties and localization in cells (Loponen et al., 2004). Salt- and water-soluble proteins (salt-soluble protein) are usually localized in cytoplasm and called cystoplasmic protein. As SDS gives a good solubilization of membrane proteins (Ames and Nikaido, 1976; Hurkman and Tanaka, 1986), SDS-soluble proteins are mainly cell membrane proteins. In this study, we examined protein content of both groups in creeping bentgrass under heat stress.

Proteins are catabolized by proteases into amino acids, and derived amino acids may be transported to growth or storage organs during leaf senescence (Feller and Fischer, 1994; Peoples and Dalling, 1988). Protein loss and increased protease activity could be markedly accentuated by high temperature stress, which may accelerate leaf senescence (Al-Khatib and Paulsen, 1984).

Despite the importance of heat-induced leaf senescence for cultivation of cool-season turfgrasses, the underlying mechanisms are not well understood. How changes in amino acid accumulation, protease activity, and protein degradation are associated with heat injury in cool-season turfgrasses, and the level of high temperatures or duration of heat stress causing changes in these metabolic factors are not clear. Therefore, the objectives of this study were to 1) examine protein and amino acid content, protease activity, and lipid peroxidation of creeping bentgrass in response 
to GHS and PHS; and 2) determine level of temperature and duration of heat stress critical for metabolic changes associated with leaf senescence and turf quality decline. The temperature levels that affect each metabolic parameter were evaluated by exposing plants to GHS (from 20 to $40{ }^{\circ} \mathrm{C}$ at $5{ }^{\circ} \mathrm{C}$ intervals). Heat stress duration that causes changes in each parameter was determined by exposing plants to heat stress $\left(40^{\circ} \mathrm{C}\right)$ for a prolonged period of time $(28 \mathrm{~d})$ and monitoring metabolic changes over time.

\section{Materials and Methods}

Plant materials and Growth Conditions. Sod plugs of 'Penncross' creeping bentgrass were collected from 3-year-old field plots at the Rutgers Univ. Horticulture Farm II, North Brunswick, N.J., in May 2002. Sods were transferred into polyvinyl chloride (PVC) tubes (10-cm diameter and $60 \mathrm{~cm}$ long) filled with washed sand. Plants were maintained in a greenhouse for 1 month and then moved into four growth chambers set at 20/16 ${ }^{\circ} \mathrm{C}$ (day/night temperature), $75 \%$ relative humidity, 14-h photoperiod, and $400 \mu \mathrm{mol}$ photons $\mathrm{m}^{-2 \cdot} \mathrm{s}^{-1}$ of photosynthetically active radiation. Plants were maintained in growth chambers for $40 \mathrm{~d}$ prior to imposing temperature treatments. Plants were fertilized once per week with $40 \mathrm{~mL}$ of full-strength Hoagland's solution (Hoagland and Arnon, 1950) and cut twice per week to keep the height at about $5 \mathrm{~cm}$.

TEMPERATURE TREATMENTS. To examine turf quality and metabolic changes with increasing temperatures, four pots of plants (four replicates) were exposed sequentially for $7 \mathrm{~d}$ to each of the following temperatures: $20,25,30,35$, and $40{ }^{\circ} \mathrm{C}$ (day/night temperature) (GHS). Leaves were sampled randomly from each pot for analysis at the end of each $5{ }^{\circ} \mathrm{C}$ temperature increment (at $7 \mathrm{~d}$ of $20^{\circ} \mathrm{C}, 20$ to $25^{\circ} \mathrm{C}, 20$ to 25 to $35^{\circ} \mathrm{C}, 20$ to 25 to 30 to $35{ }^{\circ} \mathrm{C}$, and 20 to 25 to 30 to 35 to $40{ }^{\circ} \mathrm{C}$. Therefore, treatments of GHS were expressed as $20{ }^{\circ} \mathrm{C}, 20$ to $25^{\circ} \mathrm{C}, 20$ to 25 to 30 ${ }^{\circ} \mathrm{C} ; 20$ to 25 to 30 to $35^{\circ} \mathrm{C}$, and 20 to 25 to 30 to 35 to $40{ }^{\circ} \mathrm{C}$ in Figs. 1A-5A. To determine turf quality and metabolic changes with heat stress duration, four pots of plants were moved directly from a growth chamber at $20{ }^{\circ} \mathrm{C}$ to four chambers set at $40{ }^{\circ} \mathrm{C}$ (day/night temperature), and maintained at $40^{\circ} \mathrm{C}$ for $28 \mathrm{~d}$ (PHS). During both temperature treatments, the growth chambers were set at the environmental conditions described above. Plants were watered twice per day, fertilized once per week with $40 \mathrm{~mL}$ of full-strength Hoagland's solution (Hoagland and Arnon, 1950) and cut twice per week to keep the height at $\approx 5 \mathrm{~cm}$.

EVALUATION OF TURF QUALITY AND LEAF LIPID PEROXIDATION. Turf quality was visually rated for four pots of plants exposed to either GHS or PHS treatment. Turf quality was evaluated based on turf color and shoot density on a scale of 0 (worst, plants were brown and dead) to 9 (best, plants were green and healthy).

The level of lipid peroxidation in shoots was evaluated in terms of MDA content as a measure of the severity of leaf senescence (Dhindsa et al., 1981). Malondialdehyde is a final product of peroxidation of unsaturated fatty acids in phospholipids of cellular membranes (Smirnoff, 1995). MDA content was measured using a modified method of Dhindsa et al. (1981) and Zhang and Kirkham (1994). From each of four pots at each temperature or stress duration treatment, $0.5 \mathrm{~g}$ of fresh shoots was collected and frozen in liquid $\mathrm{N}_{2}$. Frozen tissues were ground in $4 \mathrm{~mL}$ solution containing $50 \mathrm{~mm}$ phosphate buffer $(\mathrm{pH}$ $7.0)$, and $1 \%(\mathrm{w} / \mathrm{v})$ polyvinylpolypyrrolidone. The homogenate was centrifuged at $15000 g_{\mathrm{n}}$ for $20 \mathrm{~min}$, and supernatant (leaf extraction) was collected and used for MDAcontent measurement.
A 2-mL aliquot of leaf extraction solution was added to a tube containing $1 \mathrm{~mL} 20 \%(\mathrm{v} / \mathrm{v})$ trichloroacetic acid and $0.5 \%(\mathrm{v} / \mathrm{v})$ thiobarbituric acid. The mixture was heated in a water bath at 95 ${ }^{\circ} \mathrm{C}$ for $30 \mathrm{~min}$, cooled to room temperature, and then centrifuged at $10,000 g_{\mathrm{n}}$ for $10 \mathrm{~min}$. The absorbance of the supernatant at 532 $\mathrm{nm}$ was determined and the nonspecific absorbance at $600 \mathrm{~nm}$ was subtracted using a spectrophotometer (Spectronic Genesys 2; Spectronic Instruments, Rochester, N.Y.). The MDA content was calculated using the extinction coefficient of $155 \mathrm{~mm}^{-1} \cdot \mathrm{cm}^{-1}$ (Heath and Packer, 1968).

Protein EXTRaCtion AND Quantification. Protein content was measured using the method of Bradford (1976). A 0.5-g sample of fresh leaves was collected from each of four pots in each treatment. Frozen shoots were ground in liquid $\mathrm{N}_{2}$ to fine powder. Protein was extracted in $3 \mathrm{~mL}$ of Tris- $\mathrm{HCl}$ buffer $(0.10 \mathrm{~mm}$ This$\mathrm{HCl}$, and $0.15 \mathrm{M} \mathrm{NaCl}$ ( $\mathrm{pH}$ 7.6). Samples were then centrifuged twice at $16,000 g_{n}$ at $4{ }^{\circ} \mathrm{C}$ for $0.5 \mathrm{~h}$ to get a clear supernatant for hydrophilic protein content measurement. The pellet was subsequently re-suspended with $3 \mathrm{~mL}$ SDS-Tris-HCl buffer $[0.10 \mathrm{~mm}$ Tris- $\mathrm{HCl}, 0.15 \mathrm{~m} \mathrm{NaCl}$, and 2\% (w/v) SDS] ( $\mathrm{pH}$ 7.6) and spun and mixed for $1 \mathrm{~h}$. Extracted suspensions were then centrifuged at $16,000 g_{\mathrm{n}}$ at $4{ }^{\circ} \mathrm{C}$ for $0.5 \mathrm{~h}$ and supernatant was collected for hydrophobic protein content measurement. Protein content was determined by the method of Bradford (1976). Briefly, $100 \mu \mathrm{L}$ of protein extraction (diluted five times) was mixed with $3 \mathrm{~mL}$ of Coomassie G-250 reagent ( $0.01 \%$ Coomassie brilliant blue $\mathrm{G}, 4.7 \%$ ethanol, and $8.5 \%$ phosphoric acid), and the absorbance was measured at $595 \mathrm{~nm}$ after 5 and $30 \mathrm{~min}$ of reaction using a spectrophotometer (Spectronic Genesys 2). Bovine serum albumin was used as a standard. Total protein content was the sum of saltsoluble protein content and SDS-soluble protein content.

Amino aCid anAlysis. Amino acid content was determined in shoots collected from each of four pots at each temperature treatment using the method of Rosen (1957) with some modifications. Briefly, fresh shoots $(1.0 \mathrm{~g})$ were frozen in liquid $\mathrm{N}_{2}$ and ground to fine powder. Amino acid was extracted in $6 \mathrm{~mL}$ of $80 \%$ ethanol. Samples were then centrifuged at $16,000 g_{\mathrm{n}}$ at $4{ }^{\circ} \mathrm{C}$ for $30 \mathrm{~min}$, and supernatant was collected for amino acid measurement. Onehalf milliliter of cyanide-acetate buffer $(0.2 \mathrm{~mm} \mathrm{NaCN}$ in $2.65 \mathrm{M}$ acetate buffer) (pH 5.4) and $0.5 \mathrm{~mL} 3 \%(\mathrm{w} / \mathrm{v})$ ninhydrin solution in methyl cellosolve (ethylene glycol monomethyl ether) were added in $1 \mathrm{~mL}$ of a 20 -times-diluted amino acid extraction. The mixed solution was heated for $15 \mathrm{~min}$ in a $100{ }^{\circ} \mathrm{C}$ water bath. Three milliliters of $50 \%$ (v/v) isopropyl alcohol-water diluents was then added in the solution and shaken vigorously. The reaction solution was allowed to cool to room temperature. The absorbance of the reaction solution was read at $570 \mathrm{~nm}$ using a spectrophotometer (Spectronic Genesys 2). Glycine was used as a standard to calculate amino acid content.

Protease activity measurement. Protease assays were performed using a modified method of Benbella and Paulsen (1998). Fresh shoots $(1.0 \mathrm{~g})$ were collected from each of four pots in each temperature treatment and were homogenized in $4 \mathrm{~mL}$ of cold medium containing $25 \mathrm{~mm} N-2$ hydroxyethylpiperazine- $N^{\prime}-2$ ethanesulfonic acid (Hepes) buffer ( $\mathrm{pH} 7.5), 1$ mM ethylenediaminetetra acetic acid (EDTA), and $4 \mathrm{~mm}$ dithiothreitol (DTT). The homogenized samples were centrifuged twice at $16000 g_{n}$ at $4{ }^{\circ} \mathrm{C}$ for $30 \mathrm{~min}$. Crude protease activity was assayed by adding $0.1-\mathrm{mL}$ aliquots of enzyme extract to $1.5-\mathrm{mL} 200 \mathrm{~mm}$ sodium citrate-citric acid buffer (pH 5.2) and $0.4 \mathrm{~mL}$ of $1 \%(\mathrm{w} / \mathrm{v})$ azocasein in test tubes. The reference tube was prepared with $0.1 \mathrm{~mL}$ of medium for protease extraction to substitute the enzyme extract. 
The tubes were incubated for $2 \mathrm{~h}$ at $37^{\circ} \mathrm{C}$. A 1-mL sample of $15 \%(\mathrm{w} / \mathrm{v})$ trichloroacetic acid (TCA) was added to sample and reference tubes to stop the reactions. Sample and reference tubes were then incubated at $4{ }^{\circ} \mathrm{C}$ for $30 \mathrm{~min}$. The resulting precipitate was removed by centrifugation at $4000 g_{n}$ for 5 min twice and supernatant was filtered by six layers of cheesecloth in a syringe. The absorbance of the clear supernatant was read at $340 \mathrm{~nm}$ in a spectrophotometer (Spectronic Genesys 2). The absorbance of the reference was subtracted from the sample. One unit of enzyme activity was defined as the changes of the absorbance by 0.1 .

STATISTICAL ANAlysis. Treatments were arranged in a randomized complete-block design with four replicates. All measurements were made in four replicates (pots), and three sub-samples from each extraction of samples in each replicate were used for the analysis of protease activity, protein content, and amino acid content. Means of the three sub-samples were used to present a single replication in analysis of variance (ANOVA). Mean separations were performed with the Fisher's protected least significance difference test at $P=0.05$ (Steel and Torrie, 1980).

\section{Results}

Changes in TURF QUality AND LiPID PEROXIDATION WITH INCREASING TEMPERATURES AND STRESS DURATION. Turf quality
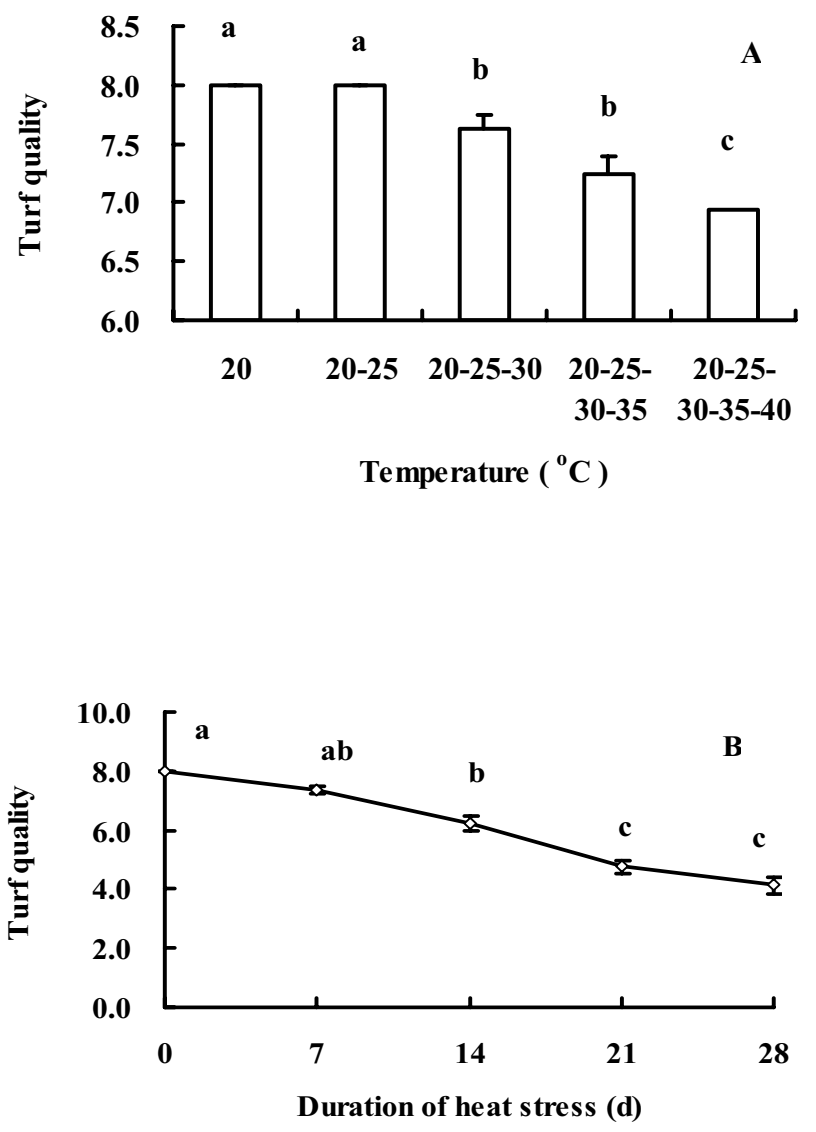

Fig. 1. Changes in turf quality of creeping bentgrass during gradual heat stress (GHS) (A), and prolonged heat stress (PHS) (B). Turf quality was evaluated based on turf color and shoot density on a scale of 0 (worst, plants were brown and dead) to 9 (best, plants were green and healthy). Different letters indicate a significant difference at $P=0.05$ among temperature treatments for GHS or different treatment durations for PHS. Bars represent SE $(\mathrm{n}=4)$ and different letters indicate a significant difference at $P=0.05$. decreased from 8.0 to 7.5 as temperature was elevated from 25 to $30{ }^{\circ} \mathrm{C}$ during the GHS treatment, and further declined to 7.0 or lower when plants were exposed to higher temperatures from 35 to $40^{\circ} \mathrm{C}$ (Fig. 1A). Turf quality also declined with increasing duration of PHS, beginning at $14 \mathrm{~d}$ of treatment $\left(40^{\circ} \mathrm{C}\right)$ (Fig. 1B). Turf quality dropped to below 6.0 by $28 \mathrm{~d}$ of PHS (Fig. 1B).

In contrast to turf quality change, leaf MDA content increased significantly under GHS (Fig. 2A). A significant increase in MDA content was first detected at $30^{\circ} \mathrm{C}$ and the increase continued at higher temperatures $\left(35\right.$ and $\left.40^{\circ} \mathrm{C}\right)$. MDA content also increased significantly with the duration of PHS, beginning at $14 \mathrm{~d}$ of treatment (Fig. 2B). MDA content by $28 \mathrm{~d}$ of PHS was almost two times as high as the pre-stress level $(0 \mathrm{~d})$. The increase in MDA content was concomitant with turf quality decline initiated at 30 ${ }^{\circ} \mathrm{C}$ during GHS and at $14 \mathrm{~d}$ during PHS treatment.

Changes IN PRotein CONTENT WITH INCREASING TeMPERATURES AND STRESS DURATION. Changes in protein content under GHS and PHS followed the same pattern as that for turf quality. Total protein content decreased during GHS from 20 to $40{ }^{\circ} \mathrm{C}$ (Fig. 3A) and as heat stress $\left(40^{\circ} \mathrm{C}\right)$ duration was prolonged to $28 \mathrm{~d}$ (Fig. 3B). The initial decline in total protein content was observed at $30{ }^{\circ} \mathrm{C}$ during GHS (Fig. 3A) and at $7 \mathrm{~d}$ during PHS (Fig. 3B). Total protein content decreased by $\approx 75 \%$ at the end of GHS and PHS.
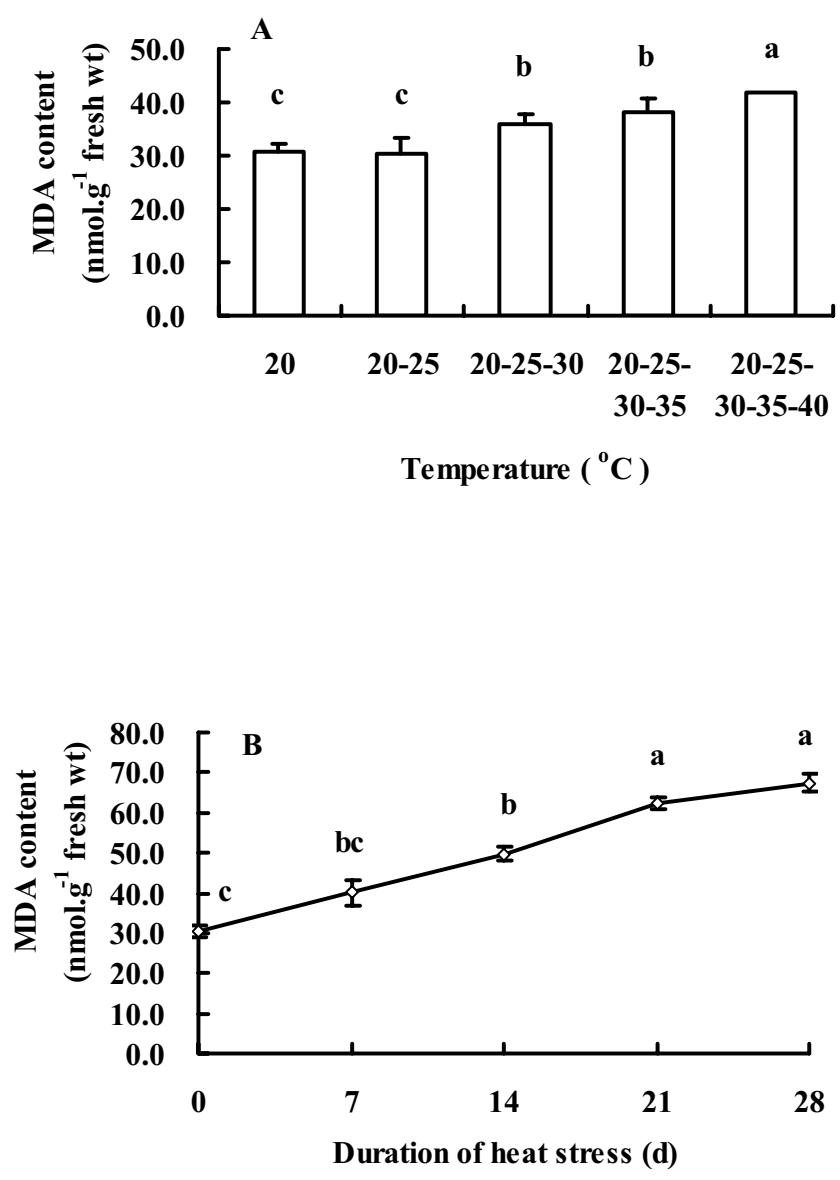

Fig. 2. Changes in malondialdehyde(MDA) content in shoots of creeping bentgrass during gradual heat stress (GHS) (A), and prolonged heat stress (PHS) (B). Different letters indicate a significant difference at $P=0.05$ among temperature treatments for GHS or different treatment durations for PHS. Bars represent SE $(\mathrm{n}=4)$ and different letters indicate a significant difference at $P=0.05$. 
CHANGES IN PROTEASE ACTIVITY WITH INCREASING TEMPERATURES AND STRESS DURATION. Protease activity increased to the highest level as temperature was elevated to $25^{\circ} \mathrm{C}(1.4$ times that at 20 $\left.{ }^{\circ} \mathrm{C}\right)$ (Fig. 4A). It then decreased when temperature was further increased to 30,35 , and $40{ }^{\circ} \mathrm{C}$. In response to PHS at $40{ }^{\circ} \mathrm{C}$, protease activity increased to above the pre-stress level at $7 \mathrm{~d}$ of treatment, and then decreased with longer heat stress duration (Fig. 4B).

ChangeS IN AMINO ACID CONTENT WITH INCREASING TEMPERATURES AND STRESS DURATION. Amino acid content decreased steadily as temperature was increased from 20 to $35^{\circ} \mathrm{C}$ during the GHS (Fig. $5 \mathrm{~A})$. The initial decline was observed at $25^{\circ} \mathrm{C}$ and a significant increase when the temperature was increased from 35 to $40{ }^{\circ} \mathrm{C}$ during GHS. When plants were exposed to $40{ }^{\circ} \mathrm{C}$ for prolonged duration, amino acid content increased at $7 \mathrm{~d}$ of treatment, but then decreased gradually from 7 to $28 \mathrm{~d}$ (Fig. 5B).

\section{Discussion}

The results in this study suggested that GHS to $30{ }^{\circ} \mathrm{C}$ and PHS at $40{ }^{\circ} \mathrm{C}$ for $14 \mathrm{~d}$ was detrimental for creeping bentgrass, as manifested by the accelerated leaf senescence (measured as increased lipid peroxidation) and turf quality decline. Huang and Gao (2000) also reported that $30{ }^{\circ} \mathrm{C}$ was the threshold for turf

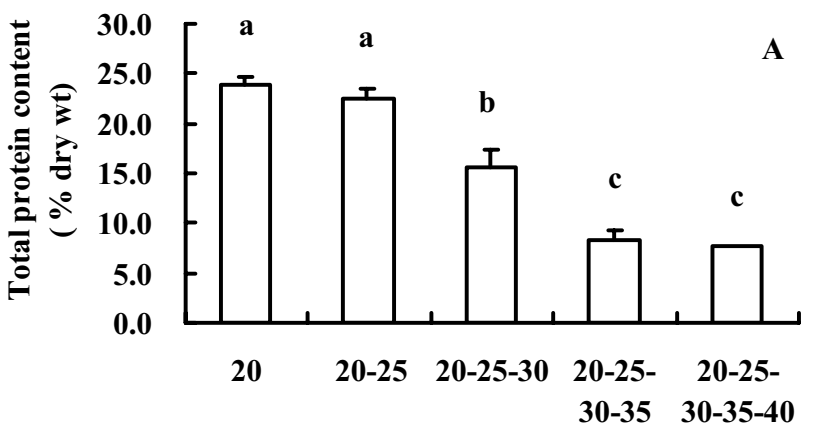

Temperature $\left({ }^{\circ} \mathrm{C}\right)$

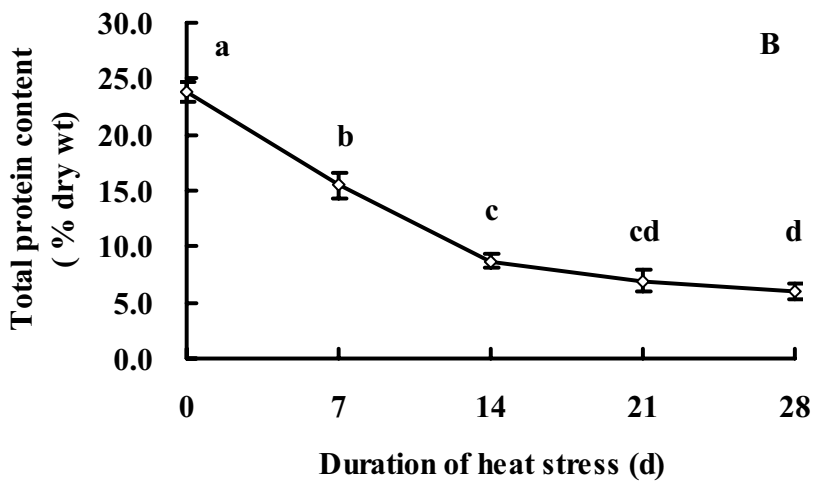

Fig. 3. Changes in total protein content in shoots of creeping bentgrass during gradual heat stress (GHS) (A), and prolonged heat stress (PHS) (B). Different letters indicate a significant difference at $P=0.05$ among temperature treatments for GHS or different treatment durations for PHS. Bars represent SE $(n=4)$ and different letters indicate a significant difference at $P=0.05$. quality decline in creeping bentgrass in a separate study. They attributed turf quality decline above $30{ }^{\circ} \mathrm{C}$ to the imbalance between photosynthesis and respiration and limited carbohydrate availability. The present study demonstrated that heat-induced leaf senescence and turf quality decline could also be related to changes in protein content, protease activity, and amino acid content, as discussed below.

Maintenance of stable proteins in a highly organized state is important for proper functions of cells during high temperature stress due to their involvement in metabolic processes and membrane function (Levitt, 1980). Turf quality decline and increases in MDA content were accompanied by decreases in protein content as temperature was elevated or heat stress duration was prolonged. The loss of protein occurred earlier than turf quality decline and lipid peroxidation increase during PHS, suggesting that it could contribute to long-term heat stress injury in shoots for creeping bentgrass. The reduction in total protein content under heat stress has been previously reported in other species (Chaitanya et al., 2001; Mayer et al., 1990). The progressive decrease in total protein content in shoots of creeping bentgrass under heat stress could be due to the impairment of protein synthesis and/or increased degradation. He et al. (2005) reported that synthesis of new proteins was observed in creeping bentgrass under either gradual or sudden heat stress, along with a decline in protein content. Collectively, these results suggested protein degradation could play a larger

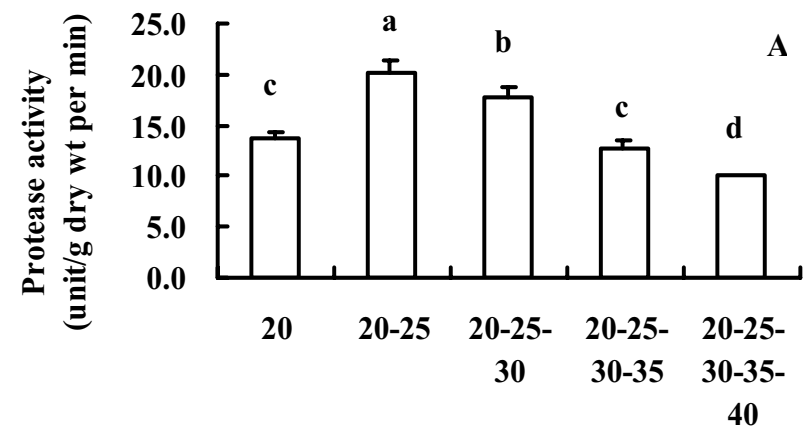

Temperature $\left({ }^{\circ} \mathrm{C}\right)$

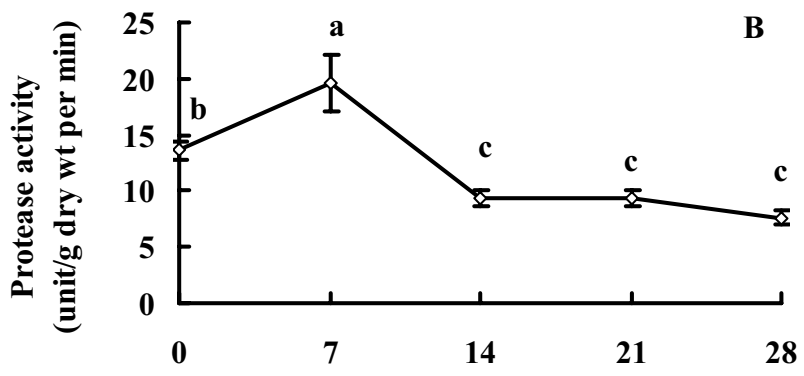

Duration of heat stress (d)

Fig. 4. Changes in protease activities in shoots of creeping bentgrass during gradual heat stress (GHS) (A), and prolonged heat stress (PHS) (B). Different letters indicate a significant difference at $P=0.05$ among temperature treatments for GHS or different treatment durations for PHS. Bars represent SE $(n=4)$ and different letters indicate a significant difference at $P=0.05$. 
role in loss of net protein than the inhibition of protein synthesis in creeping bentgrass exposed to GHS or PHS.

It has been reported previously that increased proteolytic activity is correlated with the loss of total soluble protein in foliar senescence (Feller et al., 1977; Martin and Thimann, 1972; Peterson and Huffaker, 1975). Nonspecific protease activity has been reported to increase by 4 -fold at $25^{\circ} \mathrm{C}$ and by 28 -fold at 35 ${ }^{\circ} \mathrm{C}$ from 0 to $21 \mathrm{~d}$ after the initiation of temperature treatments in winter wheat (Triticum aestivum) during grain development stage (Al-Khatib and Paulsen, 1984). Our results indicated that enhanced proteolytic activity might account for protein loss in leaves of creeping bentgrass exposed to moderately high temperature $\left(25\right.$ and $\left.30{ }^{\circ} \mathrm{C}\right)$ or short-term severe heat stress (40 ${ }^{\circ} \mathrm{C}$ for $7 \mathrm{~d}$ ).

The decline in protein with increasing temperatures to higher levels $\left(35\right.$ and $40{ }^{\circ} \mathrm{C}$ ) or heat stress for a longer duration (for 14 to $28 \mathrm{~d}$ at $40^{\circ} \mathrm{C}$ ), however, was not related to change in protease activities. The protease activities decreased as the temperature increased further to 35 and $40{ }^{\circ} \mathrm{C}$ and the heat stress prolonged longer than $7 \mathrm{~d}$. Therefore, the reduction in protease activity under higher temperatures or long-term stress may reflect heat injury in protein stability and thus enzyme functions (Levitt, 1980). Protein aggregation occurred in sweet pea (Lathyrus odoratus L.) and vinca (Catharanthus roseus L.) leaves at temperatures greater
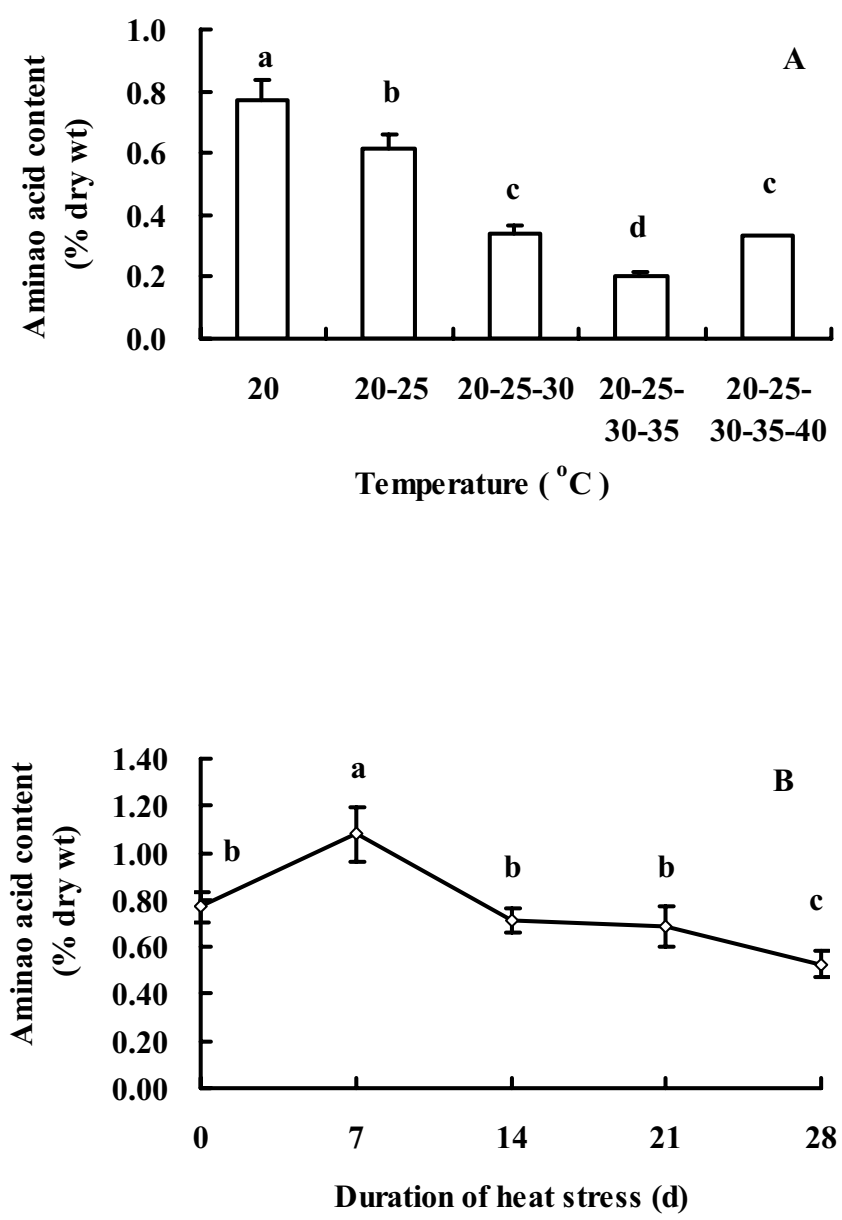

Fig. 5. Changes in amino acid content in shoots of creeping bentgrass during gradual heat stress (GHS) (A), and prolonged heat stress (PHS) (B). Different letters indicate a significant difference at $P=0.05$ among temperature treatments for GHS or different treatment durations for PHS. Bars represent SE $(n=4)$ and different letters indicate a significant difference at $P=0.05$. than $40{ }^{\circ} \mathrm{C}$ (Anderson and Padhye, 2004). As the loss of protein is a dominant feature of leaf senescence during heat stress and much of the protein is probably catabolized by specific proteases (Martin and Thimann, 1972), further studies are required to identify and characterize specific senescence-related proteases in order to understand proteolytic mechanisms responsible for heat-induced protein degradation and leaf senescence.

The decline in protein content during heat stress has been found to be associated with an increase in free amino acid accumulation in some plant species, such as wheat (Al-Khatib and Paulsen, 1984) and mulberry (Morus alba L.) (Chaitanya et al., 2001). In our study, within $7 \mathrm{~d}$ of heat stress at $40^{\circ} \mathrm{C}$, increased total amino acid content paralleled the decrease in protein content and the increase in protease activity. During the initial stage of leaf senescence, proteins must be degraded by peptide hydrolases to amino acids prior to the export of the protein nitrogen (Feller, 1990; Peoples and Dalling, 1988). However, the decrease of protein content was not always paralleled by the accumulation of amino acid. As heat stress prolonged to 14, 21, and $28 \mathrm{~d}$, amino acid content also decreased. Our results suggest that the changes of protein content, protease activity, and amino acid levels and their relationship under stress were dependent on the temperature level and the duration of heat stress.

Amino acid content is not only affected by proteolysis, but also is determined by other processes, including amino acid synthesis, compartmentalization, transport of amino acids, and metabolism to other end-products (Noctor et al., 2002). The decline in amino acid content in leaves may reflect remobilization of amino acids from senescent leaves into other tissues to cope with the highenergy demands augmented during high temperature stress. Levitt (1980) suggested that evolution of heat adaptation could involve conformational flexibility, perhaps partly through reallocation of certain amino acids. The decline in amino acid content under severe heat stress could also be related to the leakage from cells through damaged membranes. Increased amino acid leakage has also been detected in creeping bentgrass exposed to heat stress ( 35 ${ }^{\circ} \mathrm{C}$ ), which has been associated with lipid peroxidation (Larkindale and Huang, 2004). In fact, lipid peroxidation was enhanced in response to GHS or PHS in this study, although direct leakage of amino acid was not examined.

Comparing temperature- and time-responses of different parameters revealed that protease activity and amino acid content were more sensitive indictors of heat injury than other parameters examined. The changes in protease and amino acid occurred at $5{ }^{\circ} \mathrm{C}$ lower or $7 \mathrm{~d}$ earlier than the changes in protein content (at $30{ }^{\circ} \mathrm{C}$ GHS) and membrane lipid peroxidation and turf quality decline (at $30{ }^{\circ} \mathrm{C}$ of GHS and $14 \mathrm{~d}$ of PHS). These results also suggested that heat injury in creeping bentgrass, as manifested by turf quality decline, under GHS or PHS, was associated with decreases in protease activity, amino acid content, protein content, and increases in lipid peroxidation.

\section{Literature Cited}

Al-Khatib, K. and G.M. Paulsen. 1984. Mode of high temperature injury to wheat during grain development. Physiol. Plant. 61:363-368.

Ames, G.F.-L. and K. Nikaido. 1976. Two-dimensional gel electrophoresis of membrane proteins. Biochemistry 15:616-623.

Anderson, J.A. and S.R. Padhye. 2004. Protein aggregation, radical scanvenging capacity, and stability of hydrogen peroxide defense systems in heat-stressed vinca and sweet pea. J. Amer. Soc. Hort. Sci. 129:54-59.

Benbella, M. and G.M. Paulsen. 1998. Efficacy of treatments for delaying 
senescence of wheat leaves: I. Senescence under controlled conditions. Agron. J. 90:329-332.

Bradford, M.M. 1976. A rapid and sensitive method for the quantitation of microgram quantities protein using the principle of protein-dye binding. Anal. Biochem. 72:248-254.

Callis, J. 1995. Regulation of protein degradation. Plant Cell 7:845857.

Chaitanya, K.V., D. Sundar, and A.R. Reddy. 2001. Mulberry leaf metabolism under high temperature stress. Biologia Plant. 44:379-384.

Dhindsa, R.S., P.P. Dhindsa, and T.A. Thorpe. 1981. Leaf senescence: Correlation with increased levels of membrane permeability and lipid peroxidation, and decreased levels of superoxide dismutase and catalase. J. Expt. Bot. 32:93-101.

DiPaola, J. and J.B. Beard. 1992. Physiological effects of temperature stress, p. 231-262. In: D.V. Waddington, R.N. Carrow, and R.C. Shearman (eds.). Turfgrass. Monogr. 32, Amer. Soc. Agron., Madison, Wis.

Feller, U.K., T.-S.T. Soong, and R.H. Hageman. 1977. Leaf proteolytic activities and senescence during grain development of field-grown corn (Zea mays L.). Plant Physiol. 59:290-294.

Feller, U. 1990. Nitrogen remobilization and protein degradation during senescence, p. 195-222. In: Y.P. Abrol (ed.). Nitrogen in higher plants. Res. Studies Press, Somerset, U.K.

Feller, U. and A. Fischer. 1994. Nitrogen metabolism in senescing leaves. Crit. Rev. Plant Sci. 13:241-273.

He, Y., X. Liu, and B. Huang. 2005. Protein changes in response to heat stress in acclimated and nonacclimated creeping bentgrass. J. Amer. Soc. Hort. Sci. 130:521-526.

Heath, R.L. and L. Packer. 1968. Photoperoxidation in isolated chloroplasts. I. Kinetics and stoichiometry of fatty acid peroxidation. Arch. Biochem. Biophys. 125:189-198.

Hensel, L.L., V. Grbic, D.A. Baumgarten, and A.B. Bleecker. 1993. Developmental and age-related processes that influence the longevity and senescence of photosynthetic tissues in Arabidopsis. Plant Cell 5:553-564.

Hoagland, C.R. and D.I. Arnon. 1950. The solution-culture method for growing plants without soil. Calif. Agr. Expt. Circ. 347.

Huang, B. and H. Gao. 2000. Growth and carbohydrate metabolism of creeping bentgrass cultivars in response to increasing temperatures. Crop Sci. 40:1115-1120.

Huang, B., X. Liu, and Q. Xu. 2001. Supraoptimal soil temperature induced oxidative stress in leaves of creeping bentgrass cultivars differing in heat tolerance. Crop Sci. 41:430-435.

Hurkman, W.J. and C.K. Tanaka. 1986. Solubilization of plant membrane proteins for analysis by two-dimensional gel electrophoresis. Plant Physiol. 81:802-806.
Jiang, Y. and B. Huang. 2001. Drought and heat stress injury to two cool-season turfgrass in relation to antioxidant metabolism and lipid peroxidation. Crop Sci. 41:436-442.

Jiang, Y. and B. Huang. 2002. Protein alteration in tall fescue in response to drought stress and abscisic acid. Crop Sci. 42:202-207.

Larkindale, J. and B. Huang. 2004. Changes of lipid composition and saturation level in leaves and roots for heat-stressed and heat-acclimated creeping bentgrass (Agrostis stolonifera). Env. Expt. Bot. 51:57-67.

Levitt, J. 1980. Response of plants to environmental stresses. Academic, New York

Liu, X. and B. Huang. 2000. Heat stress injury in relation to membrane lipid peroxidation in creeping bentgrass. Crop Sci. 40:503-510.

Loponen, J., M. Mikola, K. Katina, T. Sontag-Strohm, and H. Salovaara. 2004. Degradation of HMW glutenins during wheat sourdough fermentations. Cereal Chem. 81(1):87-93.

Martin, C. and K.V. Thimann. 1972. The role of protein synthesis in the senescence of leaves. I. The formation of protease. Plant Physiol. 49:64-71.

Mayer, R.R., J.H. Cherry, and D. Rhodes. 1990. Effects of heat shock on amino acid metabolism of cowpea cells. Plant Physiol. 94:796-810.

Noctor, G., L. Novitskaya, P.J. Lea, and C.H. Foyer. 2002. Co-ordination of leaf minor amino acid contents in crop species: Significance and interpretation. J. Expt. Bot. 53:939-945.

Peoples, M.B. and M.J. Dalling. 1988. The interplay between proteolysis and amino acid metabolism during senescence and nitrogen reallocation, p. 181-217. In: L.D. Nooden and A.C. Leopold (eds.). Senescence and aging in plants. Academic, San Diego.

Peterson, L.W. and R.C. Huffaker. 1975. Loss of ribulose-1,5-diphosphate carboxylase and increase in proteolytic activity during senescence of detached primary barley leaves. Plant Physiol. 55:1009-1015.

Rosen, H. 1957. A modified ninhydrin colorimetric analysis for amino acids. Arch. Biochem. Biophys. 67:10-15.

Smart, C.M. 1994. Gene expression during leaf senescence. New Phytol. 126:419-448

Smirnoff, N. 1995. Antioxidant systems and plant response to the environment, p. 217-243. In: N. Smirnoff (ed.). Environment and plant metabolism: Flexibility and acclimation. Bios Sci. Publ., Oxford, U.K

Steel, R.G.D. and J.H. Torrie. 1980. Principles and procedures of statistics, 2nd ed. McGraw-Hill, New York.

Thompson, J.E., R.L. Ledge, and R.F. Barber. 1987. The role of free radicals in senescence and wounding. New Phytol. 105:317-344.

Zhang, J.X. and M.B. Kirkham. 1994. Drought-stress-induced changes in activities of superoxide dismutase, catalase, and peroxidase in wheat species. Plant Cell Physiol. 35:785-791. 